\title{
DEVELOPING KARAKTER ANIMASI BERBASIS KUDAPAN KHAS TIONGHOA
}

\author{
Claudia Octaverina Sumarli ${ }^{1)}$ Arik Kurnianto ${ }^{2)}$ \\ School of Design-Animation, Binusw University \\ Jl. Jalur Sutera Barat No.21 Tangerang, Banten 15143 \\ claudia.sumarli@gmail.com ${ }^{1)}$ arikkurnia@binus.ac.id ${ }^{2}$
}

\begin{abstract}
Abstrak
Kudapan khas Tionghoa merupakan salah satu jenis makanan ringan yang mempunyai bentuk dan cerita yang unik contohnya seperti kue bakpao, kue bulan dan lain-lain. Selain itu kudapan khas Tionghoa sudah banyak dikenal dan disukai masyarakat luas. Perancangan ini bertujuan untuk membuat karakter serial animasi buatan lokal berbasis kudapan khas Tionghoa. Untuk mendapatkan hasil yang valid maka dilakukan penelitian dengan metode kualitatif melaui wawancara, observasi dan studi pustaka untuk mengetahui cara pembuatan karakter dan berbagai macam kudapan khas Tionghoa. Hasil penelitian tersebut berupa berbagai alternatif-alternatif visual karakter kudapan Khas Tionghoa yang menggambarkan keunikan bentuk kudapan tersebut dan menjadi karakter buatan indonesia yang bisa digemari.
\end{abstract}

Kata Kunci: Karakter, Kudapan Khas Tionghoa, Animasi.

\begin{abstract}
Chinese Snacks were one of the foods that have different kinds of unique shapes and stories, such as baozi, mooncake and others, that were mostly well known by most people worldwide. by using qualitative reserach method such as interviewing, observing and literature review, This research was aimed to developed a local character that was based on some of the chinese snack. Which later on will have an output such as some alternatif character on Chinese snacks that shows their unique shapes and sizes.

Keyword: Character, Chinese Snacks, Animation
\end{abstract}




\section{PENDAHULUAN}

Film animasi dewasa ini berkembang dengan pesat, meskipun film animasi ditujukan untuk anak-anak, tidak sedikit juga remaja dan orang dewasa yang menikmatinya. Di Indonesia, industri keratif pun juga berkembang bisa dilihat dari beberapa animasi buatan lokal yang mulai tayang di televisi seperti animasi Adit dan Sapo Jarwo, Entong, dan Keluarga Somat.

Tetapi siaran film animasi di televisi nasional termasuk sangat minim di Indonesia, masih banyak film-film luar yang merajai acara televisi Indonesia seperti animasi 2D yaitu Spongebob Squarepants dan Doraemon, animasi 3D yaitu Upin Ipin dan Shaun the sheep. Hal tersebut sangat memprihatinkan, karena hal ini mengakibatkan anak-anak lebih mengenal dan menyukai karakterkarakter dari animasi luar daripada karakter-karakter dari animasi buatan lokal.

Oleh karena itu, dalam kesempatan riset ini penulis ingin membuat animasi dengan karakter berbasis kudapan khas Tionghoa yang sekaligus memperkenalkan masyarakat dengan berbagai macam jenis-jenis kudapan khas Tionghoa yang ada.

Penulis memilih tema kudapan khas Tionghoa karena kudapan khas Tionghoa mempunyai berbagai macam jenis dengan bentuk-bentuk unik dan beragam yang mempunyai sejarah tersendiri. Selain mempunyai bentuk yang unik, makanan khas Tionghoa banyak dikenal masyarakat, menurut Sisca Soewitomo (2014) masakan Chinese food sudah banyak dikenal di kalangan masyarakat luas serta disukai banyak orang. Selain itu, beberapa karakter makanan tradisional Indonesia pun ternyata terpengaruh pada budaya Tionghoa. Hal tersebut menarik penulis untuk mencari tahu lebih dalam tentang kudapan khas Tionghoa dan membuat karakter animasi berbasis kudapan khas Tionghoa.

\section{Tinjauan Pustaka}

Pengertian Animasi

Animasi berasal dari kata latin animare yang berarti "membuat hidup atau memberi nafas" (Wright, 2005). Dalam bentuk hewan atau benda nyata atau mati lainya dalam gambar 2D atau 3D. Animasi adalah sebuah porses merekam dan memainkan kembali serangkaian gambar untuk mendapatkan ilusi pergerakan. Animasi adalah usaha untuk membuat presentasi statis menjadi hidup.

Animasi bisa dipisah kedalam 4 area:

1. $2 D$ drawn animation - pembuatan animasi yang tradisional dimana pembuat masih mengambar fram 1 per 1 .

2. $2 D$ computer animation menggambar 2D dan membuat animasi dalam komputer.

3. $3 D$ computer animation - Seperti 2D computer animation tetapi menggunakan gambar yang mempunyai ruang 3 dimensi

4. Stop motion - menggunakan puppets yang ditaruh dalam sebuah set lalu digerakan dan difoto.

Prinsip Animasi

Animasi sendiri memiliki 12 prinsip. Seperti yang diadopsi dari animasi yang ada, yaitu:
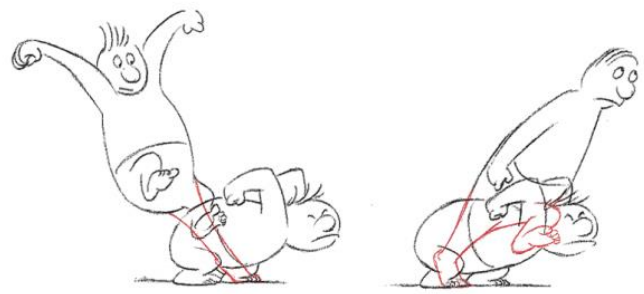

Gambar 1. Squash and stretch ( Sumber: Animator's Survival Kit: Richard Williams,2001.) 
1. Squash and stretch

Seperti bola karet, setelah ia jatuh ke lantai ia akan mengalami squash dan saat ia balik melayang ke udara akan terjadi stretch. Hal ini menentukan tingkat rigiditas suatu obyek.

2. Anticipation

Sebuah gerakan terbagi dalam 3 bagian, yaitu antisipasi, gerakan itu, dan akhir. Gerakan pendahuluan sperti menjongkok dulu sebelum meloncat adalah contoh suatu antisipasi.

3. Staging

Penempatan karakter dihadapan kamera dengan tepat supaya konsep yang diinginkan akan dengan mudah ditangkap oleh penonton.

4. Straight-ahead Action dan Pose-toPose

Pose to pose adalah dimana seorang animator menggambar key pose terlebih dahulu. Lalu ia baru menggambar inbetweennya.

5. Follow-through dan Overlapping Action

Semua gerakan tidak akan berhenti dengan waktu yang bersamaan, seringkali gerakan tersebut terasa bertindihan inilah yang disebut overlapping.

6. Slow-in Slow-out

Dari suatu pose yang diam ke sebuah gereakan pasti ada percepatan dan dari suatu yang bergerak ke sebuah gerakan diam maka ada perlambatan.

7. Arcs

Ini adalah gerakan keatas atau kebawah yang membuat bentuk lingkaran, inilah yang disebut arcs.

8. Secondary act

Secondary Act atau gerakan sekunder, ini adalah gerakan yang terjadi akibat gerakan yang lain atau gerakan utama contohnya pada saat kita melangkah maka pinggang kita ikut bergerak ke kanan dan kiri.
Gerakan sekunder tidak boleh melebihi gerakan utama.

9. Timing

Dengan durasi gerakan yang berbeda, walaupun dengan pose yang sama, suatu karakter bisa mendapatkan hasil ekspresi gerakan yang berbeda. Seperti gerak yang lambat, cepat atau normal.

10. Exaggeration

Gerakan dramatis yang ditambahkan, gerakan yang dilebih-lebihkan. Inilah exaggeration.

\section{Solid Drawing}

Kemampuan gambar yang baik menjadi peranan yang signifikan dalam proses hingga hasil animasi. Seorang animator harus peka terhadap anatomi, komposisi, pencahayaan dan dimensi sebuah karkater atau ruangan. Oleh karena itu animasi 2D atau gambar 2D bisa mempunyai kesan kedalam dan terlihat seperti tiga dimensi.

\section{Appeal}

Setiap karakter animasi harus mempunyai daya tarik tersendiri untuk membedakannya dari karakter yang lain. Salah satu caranya adalah memberi mereka personalitu dan menunjukan ekspresi pribadinya.

\section{Desain Karakter}

Dalam sebuah animasi atau komik selain cerita desain karakter sangatlah penting. Desain karakter bisa menarik minat penonton dan desain karakter yang baik mampu memberikan impact kepada para penonton. Contohnya. jika menggunakan bentuk gaya garis yang melengkung akan membuat karakter terkesan imut, dan gaya garis yang kotak akan membuat karakter terlihat agresif (White, 2013).

Menurut illustrator Jon Buregerman proses mendesain sebuah karakter merupakan salah satu hal yang paling rumit dan memakan waktu yang 
banyak untuk mendapatkan hasil yang sempurna.

Dalam pembuatan karakter ada beberapa hal yang perlu diperhatikan seperti:

\section{Target audience}

Taget audience atau sasaran, hal ini membahas tentang memikirkan para penonton. Contohnya, dalam membuat desain karakter yang ditujukan pada anak-anak, maka desain karakter biasanya menggunakan bentukbentuk dasar seperti bulat dan menggunakan warna-warna yang cerah.

2. Research other design

Research atau diartikan penelitian diperlukan untuk membantu dalam mendapatkan sebuah informasi tentang suatu karakter, mengapa ada karakter yang disukai dan tidak disukai. Pada Proses ini tidak ada hal seperti kekurangan materi untuk meriset karena materi bisa didapat darimana saja seperti; iklan, boks sereal, logo sebuah toko, sticker-sticker, film animasi, games dan lain-lain.

3. Make your character distinctive

Karakter yang baik haruslah mempunyai dampak yang kuat dan menarik sehingga bisa mendaptkan perhatian dari penonton. Karena jika mendesain suatu karakter seperti robot atau monster, pasti akan ada ratusan desain yang mirip antara satu dan lainnya.

4. Use exaggerated characteristic

Exaggerating mempunyai arti yaitu melebih-lebihkan, membuat salah satu fitur pada karakter terlihat besar atau lebih menonjol. Melebihlebihkan suatu fitur dalam karakter akan mempermudah penonton untuk bisa mengenali suatu karakter dengan mudah.

5. Choose color carefully

Warna dapat membantu mengkomunikasikan kepribadian sebuah karakter. Contohnya dengan warna- warna gelap seperti hitam, ungu dan abu-abu digunakan untuk karakterkarakter jahat atau antagonis. Sedangkan warna-warna terang seperti putih, biru, merah muda dan kuning mengekspresikan kepolosan dan kebaikan. Lalu warna-warna seperti merah , kuning dan biru juga bisa mengekspresikan bahwa karakter tersebut adalah seorang pahlawan.

6. Add accessories

Aksesoris seperti properti atau pakaian dapat membantu menjelaskan sifat dan latar belakang sebuah karakter. Seperti misalnya naju yang rombeng dan kotoro bisa digunakan untuk menjelaskan bahwa karakter tersebut adalah orang miskin. Atau aksesoris seperti burung beo yang ada di atas pundak seorang bajak laut.

7. $2 \mathrm{D}$ or $3 \mathrm{D}$

Menentukan style yang akan digunakan, bergantung dengan apa yang sudah direncanakan untuk mendesain karakter, prelu diperhatikan bentuk karakter tersebut dari sisi yang berbeda-beda. Karakter yang terlihat flat bisa mempunyai pesona lain saat dilihat dari sisi samping.

8. Give yout character personality

Karakter yang terlihat menarik belum cukup untuk membuat karakter yang baik. Kepribadian adalah kunci yang lain dalam pembuatan karakter. Kepribadian karakter tidak perlu selalu menyenangkan, tetapi kepribadian suatu karakter haruslah menarik.

9. Focus on facial expression

Tampilkan beberapa macam ekspresi pada sebuah karakter seperti ekspresi sedih, marah atau pun senang. Bergantung dengan kepribadiannya, emosi sebuah karakter bisa berbeda.

10. Give your character goals

Memberi karakater sebuah tujuan untuk dicapai, contohnya, untuk 
menjadi kaya atau untuk memecahkan masalah.

11. Build a back story

Membangun cerita sangatlah penting. Cerita memberitahu penoton tentang asal usul karakter tersebut, bagaimana karakter tersebut bisa hidup dan apa hal-hal yang ia lewati dan alami. Hal ini akan sangat membantu untuk memperkuat sebuah karakter.

\section{Get feedback from others}

Bertanya kepada orang lain dan meminta pendapat mereka. Jangan bertanya apa jika mereka menyukai karakter tersebut atau tidak. Tetapi, lihatlah apakah mereka bisa menangkap kepribadian karakter tersebut. Tanyakan pada penonton yang cocok dan ideal dan tanyakan pendapat mereka

13. Create the right environment for your character

Sama seperti membangun cerita, lingkunan sebuah karakter perlu dibuat supaya penoton bisa lebih percaya dan yakin terhadap karakter tersebut. Lingkungan dimana karakter hidup dan berinteraksi harus sebisa mungkin terlihat masuk akal.

\section{Kudapan Khas Tionghoa}

Kudapan atau bisa juga disebut sebagai makanan ringan dan camilan adalah istilah makanan yang bukan merupakan menu utama, makanan yang dianggap makanan ringan merupakan makanan untuk menghilangkan rasa lapar seseorang sementara waktu, memberi sedikit pasokan tenaga ke tubuh, atau sesuatu yang dimakan untuk dinikmati rasanya.

Kudapan mempunyai dua jenis kategoori, ada yang mempunyai citra rasa yang asin dan ada yang mempunyai citra rasa yang manis. "Jenis klasik dari asin, seperti lumpia, pastel, kroket sambosa, bitterballen tetap disukai, meskipun banyak camilan hasil modfikasi yang bermunculan. Camilan cita rasa manis juga terus menjadi promadona, seperti poffertjes, sus atau bolu." (Serimasak Femina PRIMARASA Dapur, 2016)

Menurut pengarang buku masak terkenal di indonesia, "Masakan Chinese food sudah banyak dikenal di kalangan masyarakat luas serta disukai banyak orang." (Soewitomo, 2014). Beberapa jenis masakan khas tionghoa yang terkenal di indonesia maupun negara lain, antara lain, Dimsum, bakso, mi dan lainlain. (Deerona, Gagas Ulung) Makanan khas tionghoa pun ternyata mempunyai pengarug terhadapa makanan atau kudapan Indonesia yang ada.

Berikut adalah beberapa jenis kudapan khas tionghoa yang ada:

Egg tart

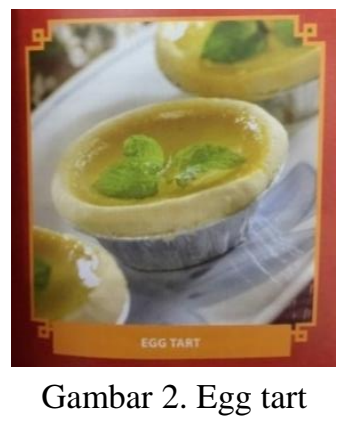

Egg tart merupakan jenis pastry yang menggunakan isian custard, pada awalnya kue ini memiliki ukuran bulat yang besar dan lalu disajika per slice. tetapi sekarang egg tart dibuat dengan ukuran sekali lahap yang lebih praktis. Egg tart ini mempunyai duau jenis yaitu yang berasal dari tionghoa, yang menggunakan crust pastry untuk dasar pie dan diisi custard yang mulus. Lalu ada yang berasal dari portuguese yang menggunakan puff pastry dengan custard yang dikaramelisasi di bagian permukaan atasnya.

Lumpia

Memiliki ciri khas pada bahan bakunya, yaitu rebung atau bambu muda. Selain itu bahan utama yang lain adalah 
udang dan telur, tepung terigu atau kulit tahu biasanya digunakan untuk menjadi pembungkusnya. Lumpia biasanya disajikan dengan cara direbus dan di goreng. Dihindangakan dan disantap dengan mengunakan saus tauco atau sambal.

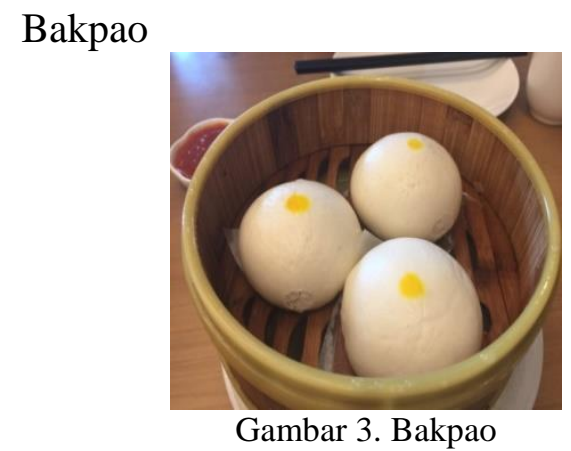

Salah satu makanan khas tionghoa yang populer di Indonesia. Kata bakpao berasal dari bahasa hokkian yang dimana bak artinya adalah daging dan pao adalah bungkusan. Biasanya diisi dengan daging, ada juga yang diisi dengan selai, kacang atau sayur-sayuran. Kulit bakpao dibuat dari adonan tepung terigu diberi ragi untuk mengembangkan adonan, setelah diberikan isian, adonan dibiarkan sampai mengembang lalu di kukus sampai matang. Untuk membedakan isi bakpao, tanpa daging (vegetarian) basanya di atas bakpao diberi titikan warna, demikian juga dengan isian yang lain diberi tanda warna yang berbeda-beda.

\section{Kue Bulan}

Dasarnya berbentuk bulat. Namun seiring waktu, bentuk-bentuk lain muncul menambah variasi tetapi tidak menghapus inti bentuk bulat tersebut. Nama lain kue bulan adalah Tiong Chiu Pia yang arti tong berarti tengah dan chiu berarti musim gugur (Zhang, 2015). Kue bulan ini biasanya dimakan pada Mid Autumn Festival yaitu festival musim gugur yang merupakan hari raya panen. Pembuatan kue bulan di Indonesia pada dasarnya berasal dari gaya pembuatan
Guangdong dan Chaozhou. Juga ada lokalisasi dengan cara pencampuran bahan-bahan yang mudah didapatkan di Indonesia, semisal daun pandan sebagai perasa.

Dan masih banyak kategorikategori lainnya hasil inovasi gaya pembuatan kue bulan gaya baru di pasaran.

\section{Jian Dui ( Onde-Onde Tausa)}

Jian dui merupakan sebuah kue goreng asal Tionghoa yang dibuat dari tepung ketan. Kue ini dilapisi dengan wijen diluarnya dan mempunyai tekstur kenyal dan garing. Didalamnya biasanya diberi isian seperti selai kacang merah atau selai kacang hitam, kalau di Indonesia makanan ini disebut ondeonde. Di zaman sekarang terdapat beberapa variasi warna pad permukannya seperti putih, merah dan hijau, yang merupakan onde-onde khas dari Mojokerto

\section{Shaomai}

Shaomai merupakan salah satu jenis dimsum, shao mai mempunyai arti dimana shao adalah masak dan mai adalah jual. Dalam masakan Tionghoa shaomai berisi daging babi cincang yang dibungkus kulit yang serupa dengan kulit pangsit, ada juga shaomai yang dibuat dengan camputan udang, daging dan jamur lalu dibuat kedalam bentuk silinder dan diatasnya diberikan telur ikan atau kepiting. Berbeda halnya dalam masakan Indonesia, Shaomai membunyai variasi isian dari daging ikan hingga ayam lalu dicampur juga dengan sagu dan ada beberapa yang tidak dibungkus dengan kulit. Biasanya disajikan dengan telur atau pare dan dilumuri dengan saus kacang.

\section{Chong fan}

Chong fan atau Rice noodle roll adaalah makanan khas Tionghoa. 
Biasanya disajikan sebagai cemilan, makanan kecil atau di dimsum.Chong fan adalah gulungan tipis yang terbuat dari bihun yang lebar, diisi dengan udan, daging dan sayuran.dimakan dengan dilumuri kecap asin atau dengan siumei. Ada juga yang tidak diberi isian dan diketahui sebagai jyu cheung fan yang dimana jyu cheung berarti usu babi dan fan berarti beras, nama ini diberikan karena chong fan dibulung dan menyerupai usus.Di Indonesia, biasanya chong fan disajikan dengan dilumuri saus cabai dan di beberapa daerah ada chong fan dengan bentuk segitiga dan diberi isian pepaya atau benkoang.

\section{Kue Keranjang}

Kue keranjang atau bisa juga disebut debagai Nian Gao adalah kue yang terbuat dari tepung ketan dan gula, serta mempunyai tekstur kenyal dan lengket. Kue keranjang ini merupakan salah satu menu wajib dalam perayaan tahun baru imlek. Kue keranjang juga disebut kue tahunan karena hanya dibuat setahun sekali pada masa menjelang tahun baru imlek. Pada zaman dahulu banyaknya atau tingginya kue keranjang menandakan kemakmuran keluarga pemilik rumah. Biasanya kue ini disusuan keatas dan adalah simbol kehidupan yang manis yang kian menanjak dan mekar.

\section{METODE RISET DAN DESAIN}

\section{Metode Riset}

Penelitian meruapakan sebuah cara berpikir, memeriksa secaara kritis dalam berbagai aspek dan pemahaman dan merumuskan prinsip yang mengarur prosedur tertenu dan mengemabngkan dan mengujinya (Kumar, 2011)

Penelitian bisa terbagi dalam beberapa jenis, kualitatif,kuantitatif atau kombinasi. Dalam penelitian yang akan dilakukan adalah menggunakan metode kualitatif. Dimana data yang didapat atau dikumpulkan bukan berupa angka angka, melainkan data tersebut berasal dari naskah wawancara, catatan lapangan, dokumen pribadi, catatan, memo, dan dokumen resmi lainnya.

Melalui penelitian kualitatif, kita bisa mengeksplorasi beragama dimensi dunia sosial, termasuk tekstrur dan tenunan kehidupan seharihari, pengertian, pengalaman dan imajinasi peserta penelitian (Mason, 2002)

Wawancara

Penulis akan mewawancarai narasumber yang memang membidangi hal yang akan penulis teliti. Untuk mendapatkan informasi mengenai desain karakter penulis menemui pembuat karakter yang ada di Indonesia dan untuk informasi mengenai kudapan kha Tionghoa, penulis menemui chef yang mendalami masakan Tionghoa.

\section{Observasi}

Dengan melakukan observasi maka penulis akan lebih mengenal hal yang akan diteliti. Penulis meneliti beberapa kudapan khas Tionghoa yang ada dan terjun langsung unutk mencoba membuatnya. Penulis juga mengobservasi beberapa desain karakter yang ada.

\section{Studi Pustaka}

Penulis akan melakukan studi pustaka berkaitan dengan hal yang akan diriset supaya seperti cara mendesain karakter, pengertian animasi dan kudapan khas Tionghoa supaya penulis bisa mendapat pengetahuan lebih dalam mengenai hal yang akan diteliti

\section{Metode Desain}

Untuk memproduksi penelitian ini, penulis membuat pipeline dalam pembuatan agar rencana produksi tersusun dengan rapi. Metode produksi animasi ini menggunakan teknik 2D. 
Identifikasi masalah

Animasi serial yang digemari anakanak indonesia masih banyak yang berasal dan buatan dari luar negeri, yang disebakan anak-anak di indonesia lebih banyak mengenal dan menggemari karakter-karakter dari luar. Oleh karena itu penulis ingin membuat karakter yang bisa digemari anak-anak.

Ide cerita

Dengan terinspirasi dari animasi seperti canimals, animasi yang mempunyai karakter lucu dan cerita yang ringan dan menceritakan keseharian karakter. Penulis berpikir untuk membuat karakter yang lucu dan menceritakan keseharian karakter tersebut dengan beberapa temannya.

\section{Pengumpulan Data}

Penulisa akan menggunakan datadata yang di dapat dari hasil wawancara, observasi dan studi pustaka. Dengan ini maka penulis dapat mengumpulkan data baik secara langsung maupun yang tidak secara langsung.

Desain

Dengan karakter berbasis kudapan khas tionghoa yang memiliki karakteristik unik tersendiri, contoh jenisjenisnya: Siomay, kue-kue khas tionghoa atau xiao long bao.

Proses Animasi

Penulis akan membuat karakter dan background dengan teknik 2D. Membuat model karakter dan storyboard. Lalu membuat animasi dengan menggunakan program seperti after effect dan menggunakan puppet tool atau menggambar satu-satu.

\section{Compositing}

Setelah semua asset telah dibuat dan sudah di animasikan dan lain-lain. Maka penulis akan memulai compositing, dimana akan ditambahkan efek jika perlu dan juga suara atau lagu.

\section{HASIL DAN PEMBAHASAN}

\section{Judul}
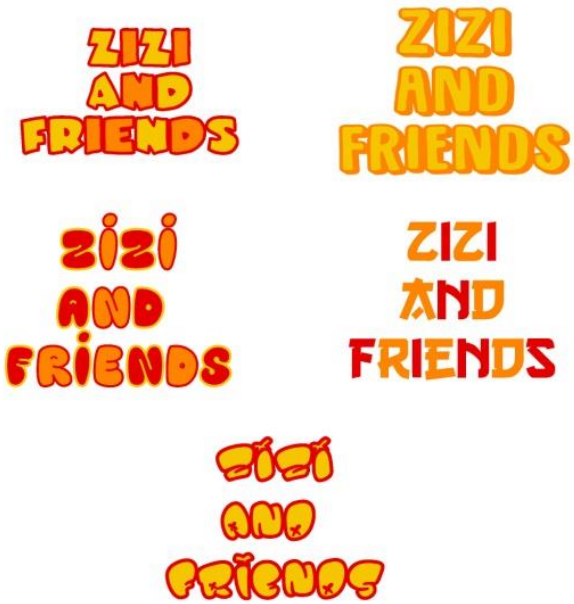

Gambar 4. Alternatif Judul

Pembuatan judul menggunakan font yang gemuk dan cenderung bulat untuk menggambarkan kesan lucu dengan warna cerah supaya tidak terlihat suram dan melambangkan konsep cerita yang berupa makanan. Maka digunakanlah warna merah, kuning dan oranye. Dimana biasanya warna merah identik dengan Tionghoa dan warna-warna ini sering digunakan untuk restoran atau makanan.

\section{Karakter \\ Zizi}
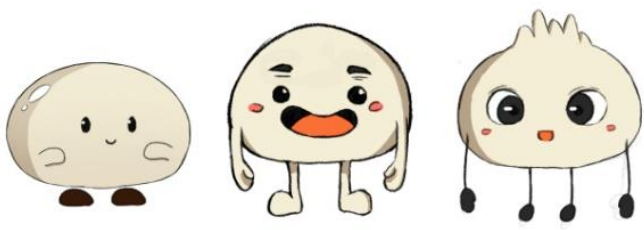

Gambar 5. Zizi

Zizi adalah karakter antrophomorphic makanan bakpao, Zizi adalah karakter bakpao berwarna putih yang ekspresif, penuh dengan keingin 
tahuan, ceria dan penakut, walau iya kadang berusaha untuk membuang rasa takutnya tapi tidak berhasil. Zizi tinggal di sebuah dapur dengan teman-temannya yaitu Shao, Tata dan Jian. Zizi mempunyai suatu obsesi tersendiri pada segala macam kacang-kacangan, terutama kacang merah. Jika dia sudah menemukan sebuah kacang ia akan mengabaikan semua yang terjadi disekelilingnya.

Shao
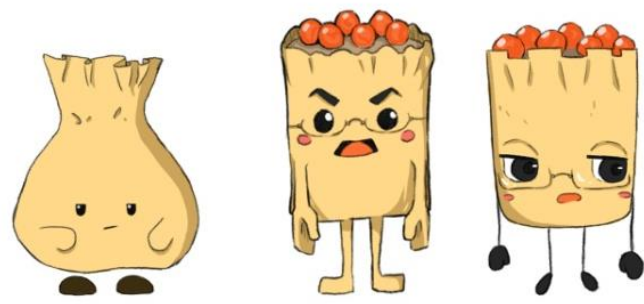

Gambar 6. Shao

Shao

merupakan

teman

sepermainan Zizi, Shao adalah karakter anthrophomorphic sebuah kudapan Siomay yang berwarna agak kekuningan dengan telur-telur ikan diatas kepalanya dan menggunakan kacamata. Shao cenderung mempunyai karakter yang serius dan kurang berekspresif seperti Zizi, walau terkadang terlihat kurang perhatian sebenarnya shao sangat peduli dengan teman-temannya.

\section{Jian}
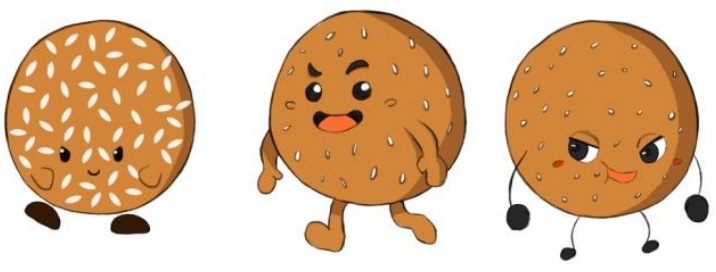

Gambar 7. Jian

Jian berbentuk bulat berwarna coklat, dengan wijen yang menempel di sekujur tubuhnya adalah sebuah karakter anthrophomorphic kue onde. Jian bertubuh gemuk dan sangat gembul.
Walau ia juga merupakan teman Zizi, ia sering sekali menjahili Zizi dan terkadang rencananya gagal atau terserang balik dengan rencananya. Jian ternyata menyukai Tata, dan selalu berusaha mendapatkan hati Tata. Tetapi ia tak kunjung berhasil.

\section{Tata}
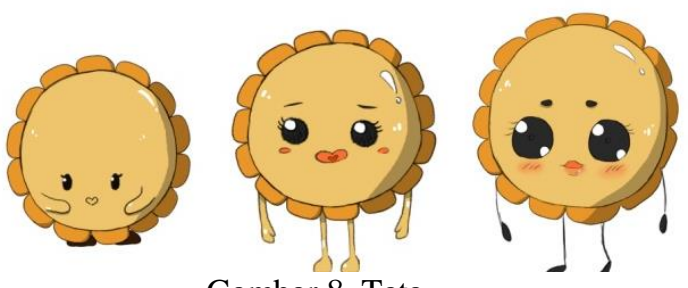

Gambar 8. Tata

Tata, karakter anthrophomorphic sebuag egg tart merupakan satu-satunya teman perempuan Zizi. Ia mempunyai bentuk seperti bunga dan mempunyai aroma manis. Tata sangat sukak bersolek dan berselfie dan hal yang tidak Tata sukai adalah serangga dan hal yang menurut Tata menjijikan. Tata selalu bersikap dingin kepada Jian dan menolak Jian karena Tata menyukai Zizi, tetapi Zizi tidak sadar dengan hal itu.

\section{Environment}

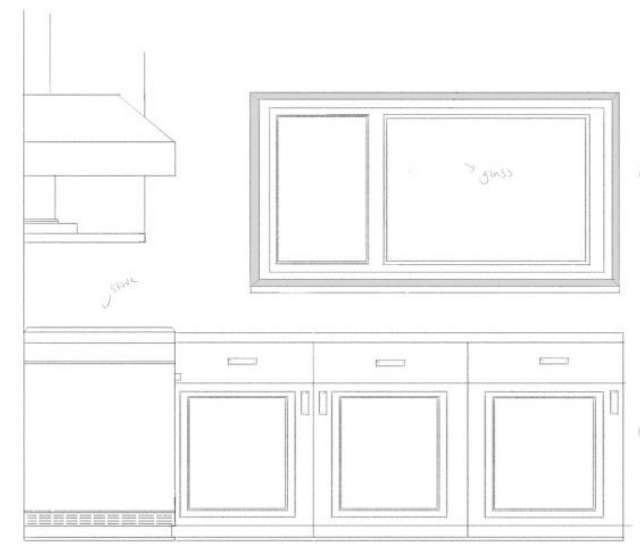




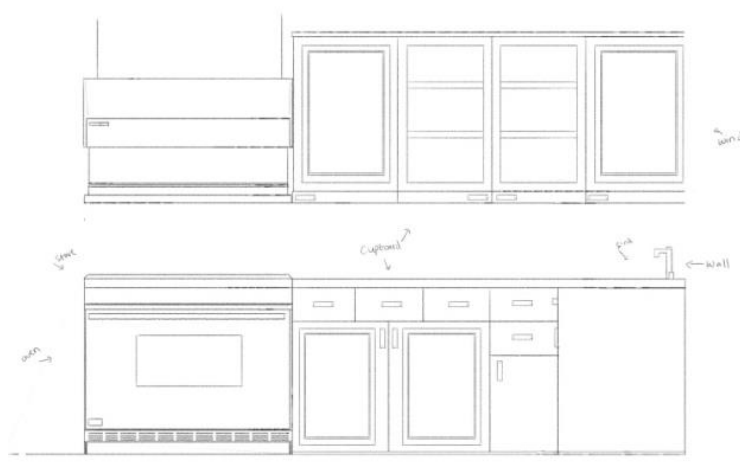

Gambar 9. Dapur

Environment Zizi dan temantemannya digambarkan dalam sebuah dapur simpel dengan warna cerah dibantu dengan cahaya jendela yang menghadap keluar.

\section{Konsep Desain}

Dalam perancangan visual yang ingin penulis hasilkan dalam karakter animasi kudapan khas tionghoa adalah sebagai berikut.
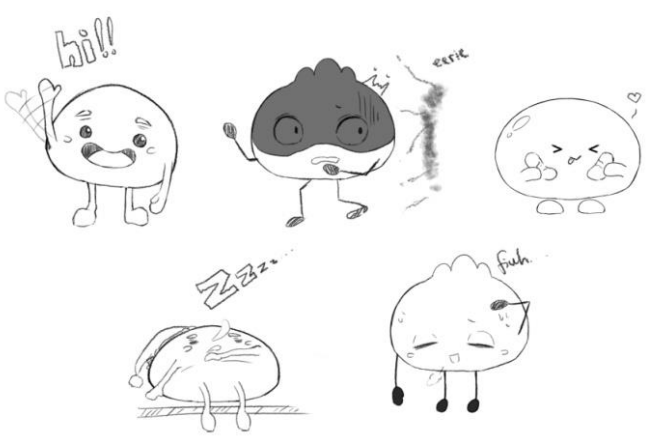

Gambar 10. Ekspresi Zizi

Karakter Zizi digambarkan sebagai sosok yang gembira, bulat dan ceria dan ekspresif. Itulah sebabnya Zizi terlihat imut, baik dan sering tersenyum atau tertawa. Tetapi walau Zizi adalah karakter yang ceria, ia juga mempunyai karakter yang penakut.
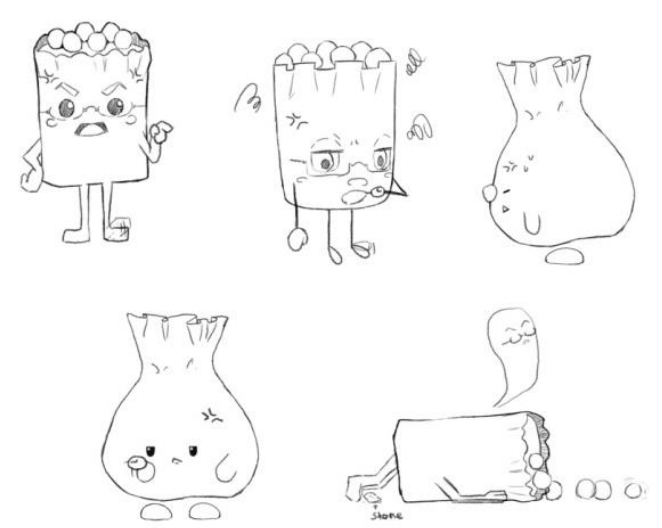

Gambar 11. Ekspresi Shao

Shaomai digambarkan sebagai sosok yang serius dan pemarah, karena dalam bahasa mandarin, Shao mai berarti masak lalu jual. Shaomai akan sering terlihat serius dan jarang tertawa.
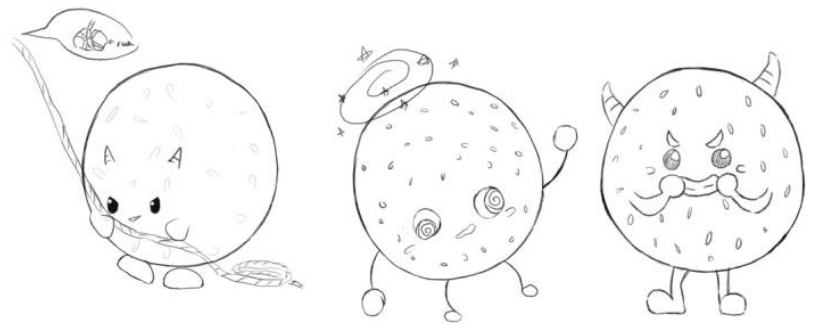

Gambar 12. Ekspresi Jian

Jian merupakan karakter yang mempunyai sifat yang jail dan gembul, dikarenakan oleh bentuk tubuhnya yang bulat dan besar.
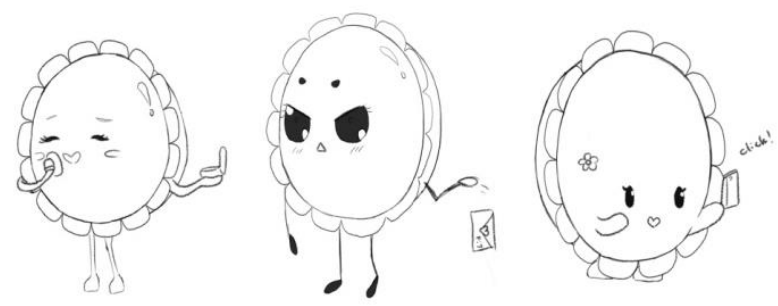

Gambar 13. Ekspresi Tata

Tata merupakan karakter yang feminim, satu-satunya karakter bergender yang bergender perempuan, karena Tata adalah satu-satunya kudapan yang manis dan terlihat seperti bunga.Tata akan 
sering terlihat berdan-dan dan mengambil selfie.

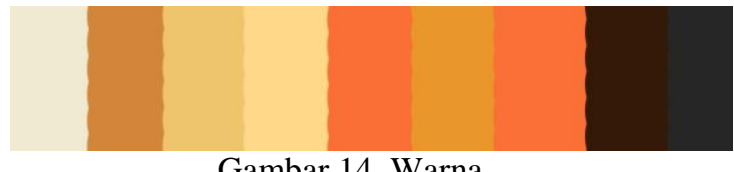

Gambar 14. Warna

Dalam perancangan karakter ini, penulis menggunakan bentuk-bentuk dasar seperti bulat dan kotak. Dengam warna yang cerah dan cenderung kecoklatan karena mengikuti warna dasar kudapan tersebut seperti putih, coklat muda dan kuning untuk memberikan kesan ceria dan senang.

\section{SIMPULAN}

Dalam pembuatan sebuah perancangan karakter untuk animasi dan animasi harus memiliki data-data yang valid untuk mengaplikasikannya kedalam karakter, cerita maupun animasi. Alasan seperti target audience, value proportition dan lain-lain juga perlu diperhatikan, karena dalam suatu karya, karya tersebut harus bisa memberikan manfaat dan mengandung arti yang baik bagi dunia animasi dan masyarakat. Maka dengan ini, dibutuhkanlah adanya suatu riset untuk mendapatkan data-data yang valid agar bisa dipertanggung jawabkan. Pada proses perancangan ini, penulislah yang melaksanakan kegiatan riset tersebut dari studi literatur, wawancara dan juga observasi untuk mendapatkan informasi yang valid yang dapat digunakan untuk pembuatan animasi, karakter dan laporan yang baik. Ide utama perancangan ini adalah keprihatinan penulis dalam dunia animasi Indonesia, dimana masih lebih banyak animasi dan karakter dari luar yang disukai masyarkat yang seharusnya animasi buatan local juga bisa digemari masyarakat luas.
DAFTAR PUSTAKA

Buku

Kumar, R. (2011). Research Methodoology 3rd edition. Padstow, Cornwall: TJ International Ltd.

Mason, J. (2002). Qualitative Researching Second Edition. Trowbridge, Wiltshire: The Cormwell Press.

Serimasak Femina PRIMARASA Dapur. (2016). Jakarta: PT. Gaya Favorit Press.

Soewitomo, S. (2014). 30 Menu 1 Bulan Chinese Food. Jakarta: Gramedia.

White, T. (2013). How To Make Animated Films. Abingdon, Oxon: Focal Press.

Williams, R. (2001). The Animator's Survival Kit. Faber and Faber.

Wright, J. A. (2005). Animation Writting And Development From Script Development To Pitch. Elseiver.

Deerona, Gagas Ulung. Jejak Kuliner China Yang Melegenda +20 Resep Masakan China Populer. Jakarta: Gramedia.

\section{Website}

Burgerman, J. (2017). 20 Charcter Design Tips. Dipetik October 22, 2017, dari Creative Blog : http://www.creativebloq.com/cha racter-design/tips-5132643/2

Mentor, A. (2017). Animation Mentor and the 12 Basic Priciples of Animation. Dipetik September 2017, dari Animation Mentor: http://blog.animationmentor.com/ 
animation-mentor-and-the-12basic-principles-of-animation/

Zhang, Y. (2015, July 23). Kuliner Kahas

Tionghoa . Dipetik 2017, dari
Tionghoa:

https://www.tionghoa.com/kuline r-khas-tionghoa/ 